\title{
Modelling of Sudan's Energy Supply, Transformation, and Demand
}

\author{
Ali A. Rabah, Hassan B. Nimer, Kamal R. Doud, and Quosay A. Ahmed \\ Energy Research Centre, Faculty of Engineering, University of Khartoum, P.O. Box 321, Khartoum, Sudan \\ Correspondence should be addressed to Ali A. Rabah; rabahss@hotmail.com
}

Received 27 March 2016; Accepted 12 June 2016

Academic Editor: Ciro Aprea

Copyright (C) 2016 Ali A. Rabah et al. This is an open access article distributed under the Creative Commons Attribution License, which permits unrestricted use, distribution, and reproduction in any medium, provided the original work is properly cited.

\begin{abstract}
The study aimed to develop energy flow diagram (Sankey diagram) of Sudan for the base year 2014. The developed Sankey diagram is the first of its kind in Sudan. The available energy balance for the base year 2012 is a simple line draw and did not count the energy supply by private and mixed sectors such as sugar and oil industries and marine and civil aviation. The private and mixed sectors account for about $7 \%$ of the national grid electric power. Four energy modules are developed: resources, transformation, demand, and export and import modules. The data are obtained from relevant Sudanese ministries and directorates and Sudan Central Bank. "e!Sankey 4 pro" software is used to develop the Sankey diagram. The main primary types of energy in Sudan are oil, hydro, biomass, and renewable energy. Sudan has a surplus of gasoline, petroleum coke, and biomass and deficit in electric power, gasoil, jet oil, and LPG. The surplus of gasoline is exported; however, the petroleum coke is kept as reserve. The deficit is covered by import. The overall useful energy is $76 \%$ and the loss is $24 \%$. The useful energy is distributed among residential (38\%), transportation (33\%), industry (12\%), services (16\%), and agriculture (1\%) sectors.
\end{abstract}

\section{Introduction}

Figure 1 shows the energy Sankey diagram of USA as an example. The Sankey diagram is an important tool to visualize the energy balance for a system or a country or a region. The Sankey diagram depicts the energy flows from supply to demand taking into account transformation. Sankey diagram was developed over 100 years ago by the Irish engineer Riall Sankey to analyze the thermal efficiency of steam engines. Since then, it has been widely used. Besides visualization, Sankey diagram is a vital tool to identify sources of inefficiency and potential saving in the energy system.

For the preparation of Sankey diagram for a country, four modules are needed. The first is the demand module, which contains the details of the demand for end-use energy (both primary and secondary fuel) for the residential, services, industrial, agricultural, and transportation sectors [1]. The demand for each sector from primary and secondary energy is defined. For example, the demand of residential sector is electricity, oil products, and biomass for lighting, cooking, and HVAC. The second module is the transformation module. It consists of all energy transformation processes, such as electricity generation, oil refining, and charcoal conversion. In these modules, the energy is divided into useful energy and lost energy. The useful energy is then distributed to demand sectors. The third module deals with the available resources. The main energy sources are coal, crude oil, natural gas, hydroelectricity, biomass, nuclear energy, and renewable energy such as solar, wind, and geothermal energy. The fourth module deals with energy import and export. There exist a number of models used to develop the energy supply and demand modules. Prominent energy models include MARKAL, LEAP, ENERGY 2020, MAPLE C, NEMS, and MAED. Details on these models and their implementation can be found in a number of published studies [2-4].

This study is aimed at providing Sankey diagram for Sudan for base year 2014. What is available now in Sudan is energy balance for 2012 [7] (cf. Table 1). However, the available energy balance data did count only the energy produced by public sectors. The energy produced by private and mixed sectors is not counted. These include the electric energy produced by oil refineries and sugar factories which constitute a significant share of Sudan energy mix. It also did not count for bagasse and bioethanol. Likewise, it does 


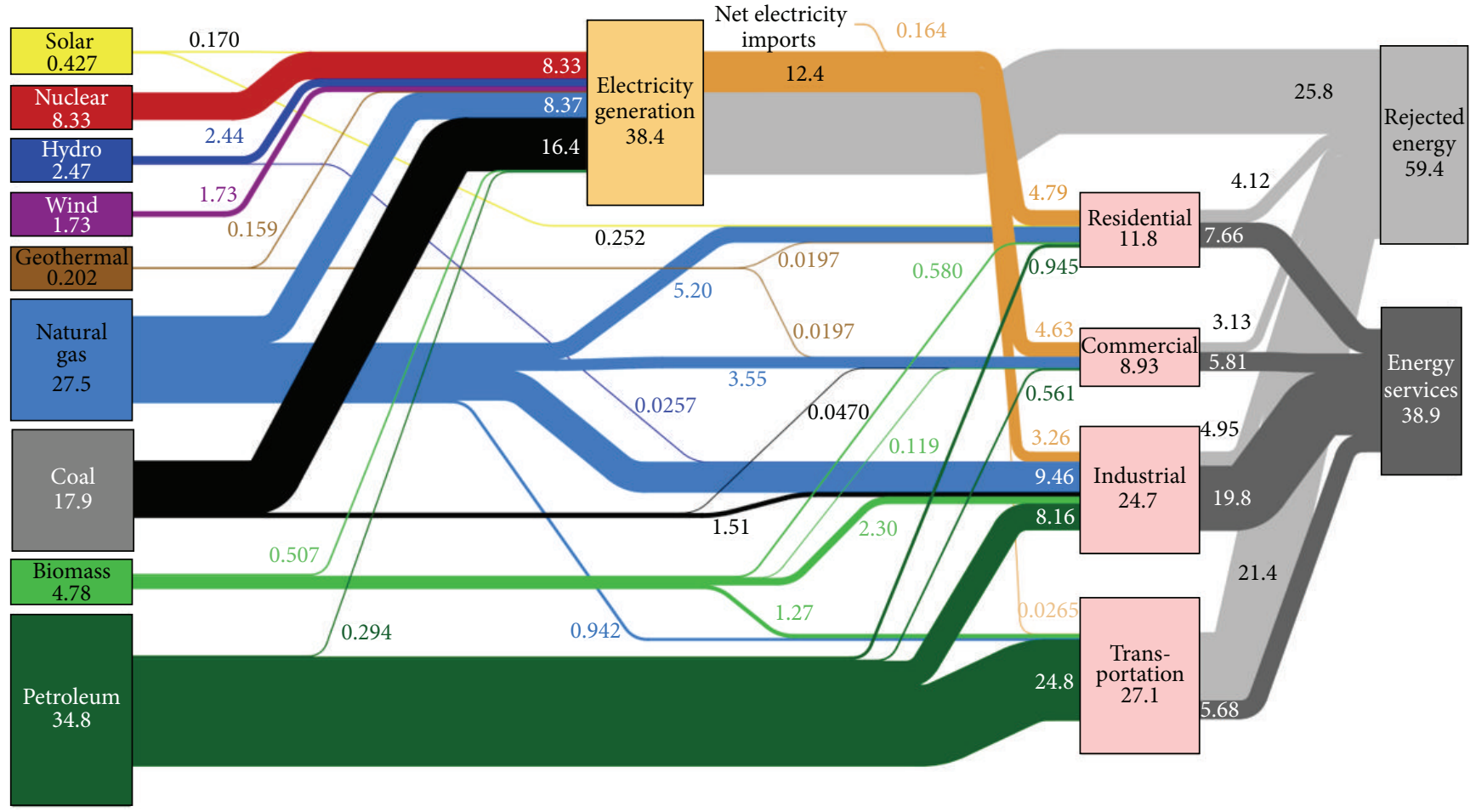

FIGURE 1: Sankey diagram of USA. Source: [5]. Data is based on DOE/EIA-0035(2015-03), March 2014. If this information or a reproduction of it is used, credit must be given to the Lawrence Livermore National Laboratory and the Department of Energy, under whose auspices the work was performed. Distributed electricity represents only retail electricity sales and does not include self-generation. EIA reports consumption of renewable resources (i.e., hydro, wind, geothermal, and solar) for electricity in BTU-equivalent values by assuming a typical fossil fuel plant "heat rate." The efficiency of electricity production is calculated as the total retail electricity delivered divided by the primary energy input into electricity generation. End-use efficiency is estimated as $65 \%$ for the residential and commercial sectors, $80 \%$ for industrial sector, and $21 \%$ for the transportation sector. Totals may not equal sum of components due to independent rounding. LLNL-MI-410527.

TABLE 1: Sudan energy balance 2012 [6].

\begin{tabular}{|c|c|c|c|c|c|c|c|c|}
\hline \multirow{2}{*}{ Demand sectors } & \multicolumn{2}{|c|}{ Power } & \multicolumn{2}{|c|}{ Oil } & \multicolumn{2}{|c|}{ Biomass } & \multicolumn{2}{|c|}{ Total } \\
\hline & ktoe & $\%$ & ktoe & $\%$ & ktoe & $\%$ & ktoe & $\%$ \\
\hline Residential & 401 & 54.3 & 298 & 7.9 & 3088 & 62.2 & 3911 & 40.0 \\
\hline Transportation & & & 2994 & 79.2 & & & 3073 & 31.4 \\
\hline Services & 181 & 24.5 & 43 & 1.1 & 1303 & 26.2 & 1579 & 16.1 \\
\hline Industry & 120 & 16.3 & 400 & 10.6 & 575 & 11.6 & 1133 & 11.6 \\
\hline Agriculture & 36 & 4.9 & 43 & 1.1 & & & 85 & 0.9 \\
\hline Total & 738 & 100 & 3778 & 100 & 4966 & 100 & 9781 & 100 \\
\hline Share of energy supply & 7.5 & & 38.6 & & 50.8 & & 100.0 & \\
\hline
\end{tabular}

not count the petroleum associated gas (AG) and renewable energy, in particular photovoltaic energy. The most difficult part of this work is the data quality check. There exist a number of reports on Sudan's energy status. These reports include conflicting data, double counts, and inconsistent units. The authors have extensively verified the data from their original sources. Data on renewable energy status in Sudan is scarce as well. Extensive search including field survey was made to collect data on this area. Data on the demand side is not well documented as well and hence enormous effort was exerted to collect the data from their original sources. The main contribution of this work is to make proper documentation of Sudan energy data on both supply and demand side. The other contribution is to produce Sudan's energy flow diagram for the first time.

\section{Methodology}

2.1. Data Collection. The energy supply, demand, and transformation data are obtained from the following reports: 


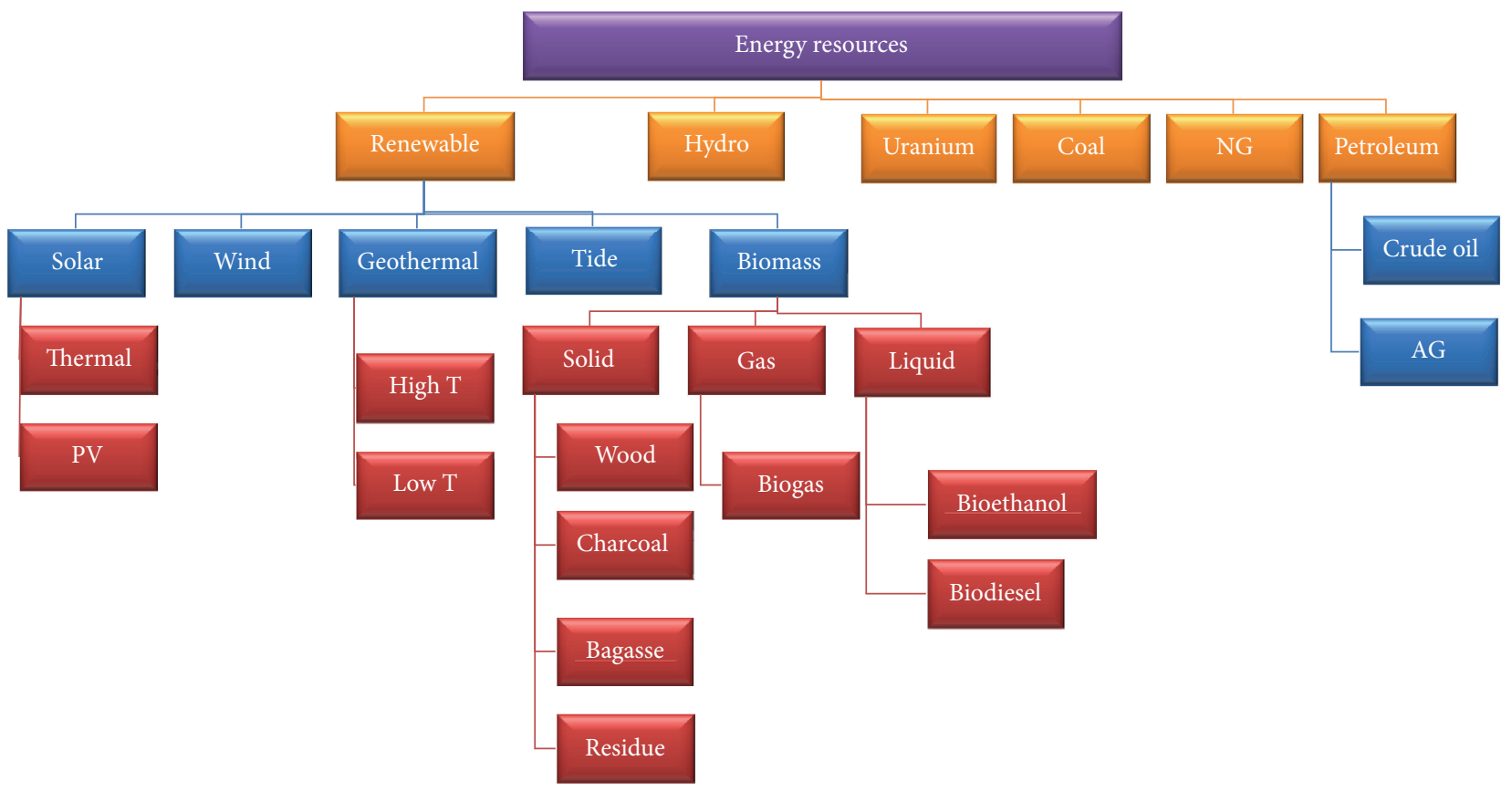

FIgURE 2: Primary energy resources.

(1) Annual report of Sudan Central Bank.

(2) Annual reports from the Ministry of Oil and Gas [6, 7].

(3) Annual report from the Directorate of Agriculture and Forestry [8].

(4) Annual report from Sudanese thermal power generation corporation [9].

The collected data is further subjected to quality check for completeness, avoiding double counting and uncertainty assessment.

2.1.1. Completeness. The available reports on electric power generation in Sudan account only for power produced by the public sector. The power generation of private and mixed sectors is not counted by the published reports. For example, the power generation of petroleum refineries and sugar factory, as mixed sectors, is not accounted for in Sudan energy balance for 2012 [6]. This data gap is filled using field survey. There also exists no inventory of standby generators countrywide.

2.1.2. Avoiding Double Counting. Some data duplicate is found in the available literature. For example, ORC produced Naphtha which is used as feedstock to KRC to produce gasoline and other products; hence, it is double counted in Sudan energy balance for 2012 and the reports of Central Bank and the Ministry of Oil and Gas. The reports of ORC and KRC refineries are considered rather than Sudan Central Bank's reports.
2.1.3. Uncertainty Assessment. There is a lack of proper documentation of bagasse, animal waste, and agriculture waste. However, there are data of production of sugar, cereals, crops, cotton, and count of animals. The waste is estimated from production data. For example, bagasse is estimated from sugar production. The sugar recovery is taken as $9 \%$ of the crushed sugar cane and the bagasse is taken as $39.5 \%$ of the crushed sugar cane. The estimated bagasse is cross-checked by field survey of the sugar plants and it is found that the assumptions are accurate within 5\% for all sugar factories. Similarly, the animal dung is estimated from animal count. The dung production is taken as 10.95, $1.83,1.83$, and 5.48 tons/animal/head for cows, sheep, goats, and camels, respectively [10]. The dung that is potential for energy use is taken as $10 \%$. The agricultural waste is estimated using harvest index (HI) [11]. The harvest index for cereals, oil crops, and cotton is taken as $0.4,0.52$, and 0.16 , respectively. The residue is calculated as amount of products multiplied by $[(1-\mathrm{HI}) / \mathrm{HI}]$. The other challenge is that the portion of agriculture residue used as fuel is unknown as the residue is shared by many applications such as animal feed, building material, and pulp and paper industry. This is on the one hand. On the other hand, the residue is mostly left in the farm as a fertilizer or burned during land preparation. Under this circumstance, the ratio of agriculture waste accepted by Sudan energy balance 2012 was considered.

2.2. Energy Modelling. Although there exist a number of energy modelling software programs such Long Range Energy Alternative Planning Systems (LEAP), in this work, a simple Excel worksheet is used for energy modelling. 


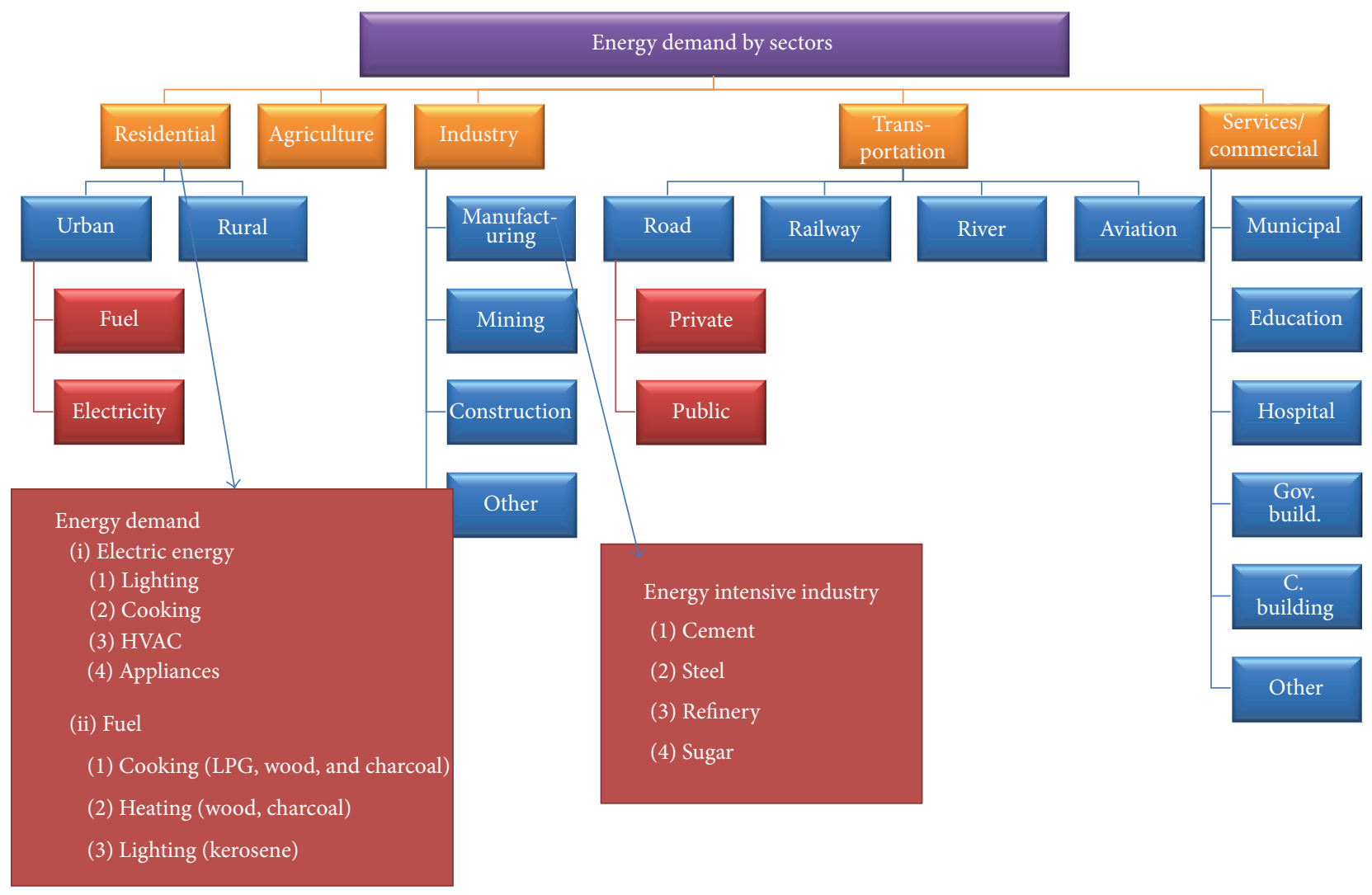

FIGURE 3: Energy demand by sector.

The energy framework for development of Sankey diagram consists of four modules [1].

(1) Energy resource module: this module takes account of all the primary fuel such as petroleum, coal, natural gas, uranium, biomass, and renewable energy (cf. Figure 2).

(2) Transformation module: the transformation module handles data on the conversion of primary fuel into secondary fuel such as power generation and conversion of crude oil in the refinery to secondary fuels.

(3) Demand module: the demand module contains the details regarding the end-use energy demand for both primary and secondary fuel. The consumption sectors include agriculture, industry, services, residential, and transportation sectors (cf. Figure 3).

(4) Import and export module: this module deals with energy import and export. The energy import and export are normally in the end-use form such as electricity and secondary fuel oil.

The data generated by the four modules for the base year 2014 is used to develop the energy Sankey diagram for Sudan. The software "e!Sankey 4 pro" was used. e!Sankey is widely used software for the development of Sankey diagrams for a country or a region.

\section{Results and Discussion}

The main sources of primary energy in Sudan are oil, hydroelectricity, biomass, and renewable energy. Coal, natural gas, and uranium are nonexistent in Sudan. The main transformation and conversion processes are electric power generation, oil refinery, and wood-to-charcoal conversion.

\subsection{Electric Energy Supply and Demand}

3.1.1. Hydroelectric Power. Table 2 shows the hydroelectric power generation plants in Sudan. The installed capacity, nominal capacity (MW), expected GWh, and year of establishment are given. The planned and under-construction hydroelectric power plants are also given. The total installed and potential hydroelectric power in Sudan is $4176 \mathrm{MW}$; the installed capacity is $1585 \mathrm{MW}(38 \%)$.

3.1.2. Thermal Electric Power Generation. Table 3 shows the installed, under-construction, and planned thermal power plants. The installed power is $1400 \mathrm{MW}$ and the underconstruction and planned power are $405 \mathrm{MW}$ and $600 \mathrm{MW}$, respectively. The installed thermal power generation is about $46 \%$ of the total installed public power generation (hydro + thermal). One important point in thermal generation is its diversity in prime movers and fuels sources. The prime movers in thermal generation include steam turbine (ST), 
TABLE 2: Hydroelectric power plant (operational, under construction, and planned).

\begin{tabular}{|c|c|c|c|c|c|}
\hline \multirow{3}{*}{ Number } & \multirow{3}{*}{ Name } & \multirow{3}{*}{ Year } & \multicolumn{3}{|c|}{ Capacity } \\
\hline & & & Installed & Nominal & Production \\
\hline & & & MW & MW & GWh \\
\hline \multicolumn{6}{|c|}{ Operational plant } \\
\hline 1 & Merowe Dam & 2009 & 1250 & 1240 & 5580 \\
\hline 2 & Roseires Dam & 1966 & 280 & 270 & 1050 \\
\hline 5 & Sennar Dam & 1962 & 15 & 12 & 49 \\
\hline 3 & Jebel Aulia Dam & 2003 & 30 & 19 & 55 \\
\hline 4 & Khasm El Girba Dam & 1964 & 10 & 10 & 15 \\
\hline & Subtotal A & & 1585 & 1551 & 6749 \\
\hline \multicolumn{6}{|c|}{ Under-construction plant } \\
\hline 5 & Upper Atbra and Sitat & 2015 & 323 & 320 & 834 \\
\hline 6 & Sennar upgrading & 2015 & 11 & 13.7 & 66 \\
\hline \multicolumn{6}{|c|}{ Planned plant } \\
\hline 7 & Shereik & & 420 & & 2103 \\
\hline 8 & Kajbar & & 360 & & 1799 \\
\hline 9 & Sabaloka & & 205 & & 866 \\
\hline 10 & Dal Low & & 648 & & 2185 \\
\hline 11 & Dagash & & 312 & & 1349 \\
\hline \multirow[t]{4}{*}{12} & Mograt & & 312 & & 1214 \\
\hline & Subtotal B & & 2257 & & 9515 \\
\hline & Total $(A+B)$ & & 384 & & 16264 \\
\hline & Available power\% & & 38 & & 39 \\
\hline
\end{tabular}

TABLE 3: Thermal power plant.

\begin{tabular}{|c|c|c|c|c|c|c|c|}
\hline \multirow{3}{*}{ Number } & \multirow{3}{*}{ Thermal power plant } & \multirow{3}{*}{ Year } & \multirow{3}{*}{ Prime mover } & \multirow{3}{*}{ Fuel } & \multicolumn{3}{|c|}{ Capacity } \\
\hline & & & & & Installed & Nominal & Available \\
\hline & & & & & MW & MW & GWh \\
\hline & \multicolumn{7}{|c|}{ Operational thermal power plants } \\
\hline 1 & Shahid Mahmoud Sharief $1+2$ ST & 1984 & $\mathrm{ST}^{1}$ & $\mathrm{HCGO}^{2}$ & 60 & 28 & 212 \\
\hline 2 & Shahid Mahmoud Sharief $3+4$ ST & 1994 & ST & $\mathrm{HFO}^{3}+\mathrm{HCGO}$ & 120 & 110 & 840 \\
\hline 3 & Shahid Mahmoud Sharief $5+6$ ST & 2011 & ST & $\mathrm{HFO}$ & 200 & 190 & 1408 \\
\hline 4 & Shahid Mahmoud Sharief $1+2$ GT & 1992 & $\mathrm{GT}^{4}$ & $\mathrm{GO}^{5}$ & 50 & 34 & 265 \\
\hline 5 & Garril: CCGT & 2003 & CCGT $^{6}$ & $\mathrm{GO}+\mathrm{LPG}$ & 180 & 170 & 1346 \\
\hline 6 & Garri2: CCGT & 2003 & CCGT & $\mathrm{GO}+\mathrm{LPG}$ & 180 & 170 & 1346 \\
\hline 7 & Garri4: ST & 2010 & ST & Pet coke & 110 & 100 & 675 \\
\hline 8 & Kusti & 2013 & ST & Crude oil & 500 & 470 & 3590 \\
\hline \multirow[t]{3}{*}{9} & Diesel generation & & IC & Diesel & & & \\
\hline & \multicolumn{4}{|c|}{ Available thermal power $A$} & 1400 & 1272 & 9682 \\
\hline & \multicolumn{7}{|c|}{ Under-construction and planned thermal power plant } \\
\hline 9 & Al Fula & 2016 & ST & $\mathrm{AG} / \mathrm{NG}^{7}$ & 405 & 381 & 2908 \\
\hline \multirow[t]{3}{*}{10} & Red Sea & 2016 & ST & Coal & 600 & 534 & 4079 \\
\hline & \multicolumn{4}{|c|}{ Planned thermal power cycle B } & 1005 & 915 & 6987 \\
\hline & \multicolumn{4}{|c|}{ Total $(A+B)$} & 2405 & 2187 & 16669 \\
\hline
\end{tabular}

\footnotetext{
${ }^{1} \mathrm{ST}$ : steam turbine.

${ }^{2}$ HCGO: heavy coker gas oil (heavy gasoil).

${ }^{3}$ HFO: heavy fuel oil (equivalent to number 6 fuel oil).

${ }^{4} \mathrm{GT}$ : gas turbine.

${ }^{5} \mathrm{GO}$ : gasoil.

${ }^{6}$ CCGT: combined cycle gas turbine.

${ }^{7}$ AG: petroleum associated gas; NA: natural gas.
} 
TABLE 4: Electric power profile (GWh).

\begin{tabular}{cccccccccc}
\hline Year & Hydro & Steam turbine & Gas turbine & Diesel & Combined & Import & Production & Hydro\% & Import\% \\
\hline 2014 & 8914 & 1400 & 0 & 202 & 864 & 469 & 11848 & 75 \\
2013 & 8317 & 1205 & 0 & 183 & 582 & 320 & 10607 & 78 \\
2012 & 6619 & 1484 & 5 & 182 & 1145 & 74 & 9509 & 70 \\
2011 & 6452 & 1631 & 1 & 161 & 210 & 0 & 8455 & 76 \\
2010 & 6199 & 473 & 14 & 192 & 620 & 0 & 7499 & 83 \\
2009 & 3236 & 887 & 94 & 309 & 1847 & 0 & 6372 & 51 & 0 \\
2008 & 1466 & 1106 & 152 & 442 & 2340 & 0 & 5506 & 27 \\
2007 & 1457 & 1057 & 371 & 140 & 1997 & 0 & 5021 & 29 \\
2006 & 1368 & 1108 & 501 & 353 & 1192 & 0 & 4521 & 30 \\
2005 & 1239 & 1047 & 319 & 385 & 1135 & 0 & 4125 & 30 \\
2004 & 1107 & 1037 & 1256 & 349 & 0 & 0 & 3749 & 30 \\
2003 & 1163 & 1168 & 210 & 328 & 0 & 0 & 3354 & 30 \\
2002 & 1287 & 116 & 381 & 310 & 0 & 0 & 3094 & 0 \\
\hline
\end{tabular}

TABLE 5: Oil industry thermal power generation plant.

\begin{tabular}{|c|c|c|c|c|c|}
\hline Number & Oil industry power plant & Year & Prime mover & Fuel & $\mathrm{kW}$ \\
\hline 1 & $\mathrm{KRC}(2 \times 12 \mathrm{MW})$ & 1999 & ST & $\mathrm{FG}^{9}+$ bunker & 24000 \\
\hline 2 & $\mathrm{KRC}(2 \times 12 \mathrm{MW})$ & 2006 & GT & FG + bunker & 12000 \\
\hline 3 & ORC $50 \mathrm{~Hz}$ & 1999 & IC & Diesel & 250 \\
\hline 4 & ORC $60 \mathrm{~Hz}^{8}$ & 1999 & IC & Diesel & 500 \\
\hline 5 & Heglig oil field 1 & na & IC & Diesel & 25.5 \\
\hline 6 & Heglig oil field 2 & na & IC & Diesel & 11.5 \\
\hline 7 & Neem oil field & na & IC & Diesel & 11.2 \\
\hline 8 & Canar oil field & na & IC & Diesel & 0.8 \\
\hline 9 & Diffra oil field & na & IC & Diesel & 3.9 \\
\hline 10 & Other (mainly the power for the oil pipeline) & na & IC & Diesel & 1000 \\
\hline & Tota & & & & 37803 \\
\hline
\end{tabular}

${ }^{8} \mathrm{FG}$ : fuel gas mainly $\mathrm{CH}_{4}$.

${ }^{9}$ Since 2014 , it has become standby generator as the refinery is connected to national grid of $50 \mathrm{~Hz}$.

gas turbine (GT), combined cycle of gas turbine (CCGT), and internal combustion (IC) engines. IC engines are used in remote areas that are not covered by the national grid. The fuels used include gasoil (GO), diesel (blend of gasoil and gasoline), heavy fuel oil (HFO) also called furnace and number 6 fuel oil, heavy coker gasoil (HCGO), crude oil, petroleum coke, and liquefied petroleum gas (LPG). Diversity is a merit; however, the use of gasoil in steam turbine is the weak point of thermal generation sector in Sudan. Gasoil is competitive oil as it is used by transportation and agriculture sectors, in addition to its high cost relative to heavy fuel oil and petroleum coke. But it seems that the use of gasoil in ST and GT generation is an issue of "energy security" rather than economic factors; otherwise, the use of gasoil is not a common practice in ST and GT power generation. Table 4 shows the electric power generation in Sudan in the period from 2002 to 2014 . The hydroelectric power share increased from $42 \%$ in 2002 to more than $75 \%$ in 2014 . This is mainly due to the inception of Merowe Dam in 2009. The imported electric power from Ethiopia increased to $469 \mathrm{GWh}(4 \%)$ in 2014.
3.2. Private and Mixed Sectors Power Generation. There exist a number of private and mixed industries that produce their own power consumption. The major industries are as follows:

(1) Oil refineries.

(2) Oil fields production facilities.

(3) Sugar industry.

(4) Cement industry.

(5) Sea port and civil aviation.

(6) Others.

The power production by these sectors is not accounted for in Sudan energy balance 2012.

3.2.1. Oil Refinery. Table 5 shows the installed power of oil refinery and oil fields. The total installed power by oil industry is about $38 \mathrm{MW}$. A large portion of KRC refinery power generation is from waste heat and low grade fuel such as vent gas and oil slope (slurry). The electric power produced by oil 
TABLE 6: Sugar industry power plant [12].

\begin{tabular}{|c|c|c|c|c|c|c|c|c|c|}
\hline \multirow{3}{*}{ Number } & \multirow{3}{*}{ Factory } & \multirow{3}{*}{ Year } & \multicolumn{2}{|c|}{ Sugar capacity } & \multirow{2}{*}{\multicolumn{2}{|c|}{ Bagasse $^{10}$}} & \multirow{2}{*}{\multicolumn{3}{|c|}{ Power plant }} \\
\hline & & & Installed & Current & & & & & \\
\hline & & & kton & kton & kton & ktoe & MW & $\mathrm{D} / \mathrm{Y}$ & GWh \\
\hline 1 & Kenana & 1981 & 300 & 307.6 & 1350 & 580 & 20 & 210 & 326 \\
\hline 2 & Sennar & 1976 & 70 & 73.1 & 321 & 138 & 6.5 & 210 & 33 \\
\hline 3 & Assalaya & 1980 & 70 & 65.4 & 287 & 123 & 6.5 & 210 & 33 \\
\hline 4 & Guneid & 1962 & 70 & 73.1 & 321 & 138 & 6.0 & 210 & 30 \\
\hline 5 & New Halfa & 1966 & 70 & 59.5 & 261 & 112 & 6.0 & 210 & 30 \\
\hline \multirow[t]{2}{*}{6} & White Nile ${ }^{11}$ & 2012 & 450 & 73.4 & 322 & 138 & (104) $6.0^{12}$ & 210 & 33 \\
\hline & Total & & 980 & 652.1 & 2862 & 1230 & (190) 96 & & 485 \\
\hline
\end{tabular}

${ }^{10}$ Bagasse sugar ratio: 4.4 .

${ }^{11}$ The design capacity of power plant is $104 \mathrm{MW}$.

${ }^{12}$ Personnel contact.

TABLE 7: Solar radiation and sunshine duration in Sudan [13].

\begin{tabular}{|c|c|c|c|}
\hline Station & $\begin{array}{c}\text { Mean temperature } \\
\mathrm{C}\end{array}$ & $\begin{array}{c}\text { Sunshine duration } \\
\mathrm{h}\end{array}$ & $\begin{array}{c}\text { Solar radiation } \\
\mathrm{MJ} / \mathrm{m}^{2} / \text { day }\end{array}$ \\
\hline Port Sudan & 28.4 & 9.0 & 20.87 \\
\hline Shambat & 29.7 & 9.9 & 22.82 \\
\hline Wadi Medani & 28.4 & 9.8 & 22.84 \\
\hline ElFashir & 25.8 & 9.6 & 22.80 \\
\hline Abu Na'ama & 28.8 & 8.8 & 21.90 \\
\hline Ghazala Gawazat & 27.2 & 9.3 & 21.72 \\
\hline Dongala & 27.2 & 10.5 & 24.06 \\
\hline Toker & 28.8 & 7.3 & 17.60 \\
\hline Zalingi & 24.5 & 8.8 & 22.98 \\
\hline Babanusa & 28.2 & 8.9 & 21.30 \\
\hline Kadugli & 27.5 & 8.5 & 21.30 \\
\hline
\end{tabular}

industry is about $1 \%$ of the national grid electric power (the hydro and thermal power generation).

3.2.2. Sugar Industry. Sudan ranks high in sugar production among African countries. Sugar industry produces its own power consumption from bagasse, a byproduct of sugar cane. The installed sugar capacity is about $1.0 \mathrm{Mt}$ of sugar/year. Table 6 shows the installed capacity of electric power plants in sugar factory. The installed capacity is about $190 \mathrm{MW}$, which is about $6 \%$ of the national grid electric power. However, the available capacity is $96 \mathrm{MW}$ as the White Nile sugar factory is working at low capacity. Bagasse is sufficient to produce electric power for 210 days/year including cane crushing season of 180 days/year. Besides electric power, the factories also produce their own process heat for sugar cane mills, heating, and evaporation and crystallization process. The potential for high power generation in sugar plant is feasible. If cogeneration is installed, the process heat load will be reduced as the sugar mills and shredders will be electric driven rather than steam driven which in turn saves steam for power generation.

3.2.3. Standby Power Generation. All public utility services such as hospitals, universities, municipals, city water, and commercial buildings have their own standby IC electric power generators. However, there is lack of inventory data on standby generators countrywide. In this work, a field survey was made and about 100 standby IC generators with name plate capacity of about $1.2 \mathrm{~kW}$ with diesel as fuel source have been established. However, due to lack of information on the operation hours of the standby power generation, it is excluded in the present study. Besides services, air aviation and sea port also rely heavily on off-grid generation.

3.2.4. Photovoltaic. Table 7 shows the solar radiation in a number of Sudanese cities. The average sunshine duration is about $9 \mathrm{~h}$. Most of the solar installation in Sudan is photovoltaic cell. The total installed capacity is about $2 \mathrm{MW}$. About $50 \%$ of the installed capacity is by telecommunication industry. All remote off-grid antennas and satellites are solar driven.

3.2.5. Summary of Power Supply and Demand. Table 8 shows the power supply by various power producers and consumption by various sectors. The hydropower represents the biggest share of about $70 \%$ despite the fact that the installed capacity is about $54 \%$ of the total installed power capacity. This is due to the high outage associated with thermal power 
TABLE 8: Electric power supply and consumption in base year 2014.

\begin{tabular}{lccccccccccc}
\hline & \multicolumn{4}{c}{ Power supply (ktoe) } & \multicolumn{5}{c}{ Power demand by sectors (ktoe) } \\
& Hydro & Thermal & IC & Import & PV $^{13}$ & Residential & Industrial & Agriculture & Service & Trans. & Total \\
\hline Public sector & 767 & 677 & 17 & 40 & 0 & 534 & 151 & 52 & 283 & 0 & 1019 \\
Oil industry & & 54 & & 0 & 0 & 0 & 29 & 0 & 0 & 0 & 29 \\
Sugar industry & & 61 & & 0 & 0 & 0 & 61 & 0 & 0 & 0 & 61 \\
Renewable & & 0 & & 0 & 0.4 & 0 & 0 & 0 & 0.4 & 0 & 0 \\
\hline Total & 767 & 285 & 17 & 40 & 0 & 534 & 240 & 52 & 283 & 0 & 1109 \\
\hline$\%$ & 69.11 & 25.65 & 1.57 & 3.63 & 0.03 & 48.12 & 21.68 & 4.67 & 25.53 & 0.00 & 100.00 \\
\hline
\end{tabular}

${ }^{13} \mathrm{PV}$ : photovoltaic.

TABle 9: Oil production.

\begin{tabular}{lcc}
\hline Year & $\begin{array}{c}\text { Oil production } \\
\text { MMBPD }\end{array}$ & $\begin{array}{c}\text { Export } \\
(000 \text { tonnes }) \text { BPD }\end{array}$ \\
\hline 2014 & 42.4 & 11,093 \\
2013 & 45.1 & 15,837 \\
2012 & 37.4 & 7,210 \\
\hline
\end{tabular}

TABLE 10: Sudan refineries.

\begin{tabular}{lccc}
\hline \multirow{2}{*}{ Number } & Refinery & \multicolumn{2}{c}{ Capacity (000 tonnes) BPD } \\
& Installed & Available \\
\hline 1 & $\begin{array}{c}\text { Khartoum Refinery } \\
\text { Corporation (KRC) }\end{array}$ & 100 & 100 \\
2 & $\begin{array}{c}\text { Port Sudan Refinery } \\
\text { Corporation (PRC) } \\
\text { Obeid Refinery }\end{array}$ & 21.7 & 0 \\
4 & $\begin{array}{c}\text { Corporation (ORC) } \\
\text { Concorp Refinery }\end{array}$ & 15 & 15 \\
5 & Abu Gabra Refinery & 2 & 0 \\
\hline & Total capacity & 143.7 & 0 \\
\hline
\end{tabular}

generation. The power demand by various sectors is also given. The residential sector has the biggest share of demand followed by the service sector.

3.3. Oil Supply and Demand. Table 9 shows Sudan's oil production in the last 3 years, after the separation of South Sudan. The portion of export is given as well. Besides oil production, a significant amount of associated gas (AG) is also produced. However, the AG is not utilized; it is flared. The historical and projected daily flared amount is about 1517 MMSCFD from 2006 up to 2030 [14]. For this work, the minimum is considered (15 MMSCFD). Sudan has four oil refineries with a total installed capacity of 143.7 thousand BPD (cf. Tables 9 and 10). However, three of these refineries are out of service representing about $20 \%$ of the total installed refinery capacity.

Tables 11-17 show the fuel oil of ORC, KRC, import, total supply, total demand and supply and demand balance, and thermal power generation oil consumption, respectively. The main products include fuel oil, gasoil, kerosene, gasoline (Mogas), LPG, jet fuel, and petroleum coke. The surplus of benzene is for export. Sudan has surplus in some fuel oil
TABle 11: ORC oil products (ton/year) [6].

\begin{tabular}{cccccc}
\hline Year & Fuel oil & Gasoil & Kerosene & Naphtha & $\begin{array}{c}\text { Total } \\
\text { ktoe }\end{array}$ \\
\hline 2010 & 361641.00 & 134446.00 & 38011.00 & 26981.00 & 405 \\
2011 & 385330.00 & 141606.00 & 40405.00 & 27299.00 & 414 \\
2012 & 385352.00 & 140899.00 & 41439.00 & 24245.00 & 148 \\
2013 & 307604.00 & 114010.00 & 30937.00 & 19070.00 & 328 \\
2014 & 339663.00 & 126600.00 & 32510.00 & 24547.36 & 312 \\
\hline
\end{tabular}

and deficit in others. It has surplus in crude oil, gasoline, and pet coke. The surplus of crude and gasoline is for export while the surplus of pet coke is kept as reserve. The deficit of gasoil, LPG, and aviation is met from import. One of the causes of deficit in gasoil is its competitiveness. Gasoil is used by power generation, transportation, and agriculture sectors. As energy conservation measure fuel shift of gasoil is recommended for power generation and agriculture sector and gasoil is to be limited to transportation sector, heavy fuel oil is recommended for thermal power generation and total electrification of agricultural sector via using electric water pump for irrigation system rather than IC motors.

Table 17 shows summary of the oil supply and demand. The total supply is 7594 ktoe (7.594 Mtoe). This oil mix consists of crude oil, AG, and imported oil (gasoil, aviation, and LPG) as shown in Table 17. The imported oils represent about $19 \%$ of the total oil mix. $9.6 \%$ of the total supply is for thermal power generation including the electric power generated by $\mathrm{KRC}$ and ORC. The total energy mix is distributed as follows: $65.6 \%$ demand, $20.9 \%$ export, $12.9 \%$ energy conversion loss, and $1.32 \%$ flared gas. The demand is distributed to the following sectors: industry (11\%), residential (8\%), service $(1 \%)$, transportation $(79 \%)$, and agriculture $(1 \%)$.

3.4. Biomass. The types of biomass used for energy in Sudan include
(1) firewood,
(2) charcoal,
(3) agriculture residue,
(4) bagasse,
(5) bioethanol,
(6) animal waste. 
TABLE 12: KRC products (ton/year) [6].

\begin{tabular}{ccccccccccc}
\hline Year & Crude & Fuel oil & Gasoil & Kerosene & Benzene & LPG & Jet fuel & HCGO & Pet coke & $\begin{array}{l}\text { Total } \\
\text { ktoe }\end{array}$ \\
\hline 2010 & 4265128 & 0 & 1860390 & 0 & 1241909 & 327413 & 133616 & 379768 & 322032 & 4379 \\
2011 & 3854381 & 0 & 1651867 & 0 & 1150216 & 311840 & 133882 & 321413 & 285163 & 3964 \\
2012 & 3738191 & 0 & 1655445 & 0 & 1099800 & 319690 & 117924 & 277230 & 268102 & 3850 \\
2013 & 3403239 & 0 & 1515564 & 0 & 1009741 & 289363 & 79438 & 253612 & 255521 & 3501 \\
2014 & 3405113 & 0 & 1379208 & 0 & 1067914 & 321453 & 107074 & 293368 & 236096 & 3573 \\
\hline
\end{tabular}

TABLE 13: Fuel import (ton/year) [6].

\begin{tabular}{lrrrc}
\hline Year & Gasoil & $\begin{array}{r}\text { LPG } \\
\text { Ton }\end{array}$ & Aviation & $\begin{array}{c}\text { Total } \\
\text { ktoe }\end{array}$ \\
\hline 2010 & 337864 & 37760 & 136538 & 540 \\
2011 & 653661 & 92282 & 150459 & 945 \\
2012 & 628063 & 114013 & 109110 & 899 \\
2013 & 898842 & 195335 & 82674 & 1244 \\
2014 & 1159119 & 132903 & 66593 & 1427 \\
\hline
\end{tabular}

3.4.1. Bagasse and Ethanol. Table 18 shows the sugar produced by 6 Sudanese sugar factories. Bagasse is estimated from the produced sugar. It is taken as $39.5 \%$ of crushed sugar cane and the sugar recovery is taken as $9 \%$ of the sugar cane. Hence, the bagasse sugar ratio is 4.4-ton bagasse/ton sugar. Table 18 also shows the bioethanol production. Bioethanol is produced from molasses. All bioethanol produced is from Kenana sugar company. It should be remembered that all bioethanol is for export.

3.4.2. Firewood and Charcoal. Tables 19 and 20 show the firewood and charcoal, respectively, obtained from the annual report of the Directorate of Agriculture and Forestry of Sudan. It is clear that there is large data missing/gap. When these data are compared with data in the open literature, a large variation is found. Hence, these data are not considered and literature data is rather considered.

Table 21 shows firewood and charcoal production obtained from the open literature for some years as a crosscheck. The data of Sudan energy balance of 2012 is adopted in this work as it is close to that given by other references.

3.4.3. Agriculture Residues. Table 22 shows the cereals, oil crops, and cotton production. The agricultural waste is estimated using harvest index (HI). The harvest index for cereals, oil crops, and cotton is taken as $0.4,0.52$, and 0.16 , respectively. The agriculture waste is calculated as the amount of crop multiplied by $[(1-\mathrm{HI}) / \mathrm{HI}]$ [11]. The portion of agriculture residue used as fuel is very small as the majority is used as animal feed and building material and in pulp and paper industry, among others. On the other hand, the agriculture waste is mostly burned during land preparation for the next season. The data is cross-checked against Sudan energy balance of 2012 and is found to be consistent.
3.4.4. Animal Waste. Sudan is rich with cows, sheep, goats, and camels, besides donkeys, horses, and chickens. Table 23 shows the animal counts. The animal dung is estimated from average dung production per head. The dung is generally used for biogas production. The dung available for biogas production is estimated by many researchers as 10\% [16]. Currently, there are no reports for biogas production in Sudan. There is some biogas production in the 1980s; however, with the inception of crude oil production, biogas production was abandoned nationwide. Hence, the animal waste is not considered in the energy balance for the base year 2014 as there was no information or rates of use in the energy sector. Table 24 shows summary of biomass supply and demand.

3.5. Sankey Diagram. Sudan Sankey diagram has been developed using the energy supply, transformation, and demand data obtained for the base year 2014 (cf. Figure 4). The Sankey diagram gives a detailed flow pattern indicating the proportional consumption of primary and secondary energy in different energy demand sectors. It also shows the energy loss during transformation and conversion. The main features of the Sankey diagram are as follows:

(1) Primary energy: Sudan's primary energy consists of oil (39\%), biomass (56\%), hydroelectricity (5\%), and a very small portion of solar energy (photovoltaic). Besides primary energy, Sudan imports 1427 ktoe of fuel oils (gasoil + aviation + LPG) and 40 ktoe of electricity from the neighbouring country of Ethiopia. The import is about 7\% of Sudan's energy mix. However, natural gas, coal, nuclear energy, and other renewable energy sources are nonexistent in the country's primary energy mix, despite the huge potential of solar, wind, and geothermal energy. The high proportion of biomass is due to the large population located in rural areas (70\% rural population). They have no access to national grid electricity, fuel gas, and kerosene and therefore are absolutely biomass dependent in meeting their demand for cooking, heating, and lighting.

(2) Transformation and conversion: the transformation processes in Sudan's energy balance are power generation (hydro, oil, and bagasse), refinery of crude oil to secondary fuels, and conversion of wood to charcoal. The transformation and conversion and other losses are about $25 \%$ of the end-use energy. These losses are thermodynamic loss and energy management 
TABLE 14: Sudan fuel demand/consumption (ton) [6].

\begin{tabular}{cccccccccc}
\hline Year & Fuel oil & Gasoil & Kerosene & Benzene & LPG & AV & Pet coke & Diesel & Total \\
\hline 2010 & 555290 & 2380175 & 3018 & 824232 & 398347 & 235344 & 340858 & 26131 & 4763395 \\
2011 & 531991 & 2358366 & 3497 & 838924 & 231382 & 289474 & 211637 & 22384 & 4487655 \\
2012 & 348063 & 2544450 & 3119 & 901671 & 374968 & 223797 & 265292 & 19887 & 4681247 \\
2013 & 337800 & 2475863 & 4270 & 918269 & 357588 & 190060 & 189236 & 31088 & 4504174 \\
2014 & 290696 & 2616231 & 3744 & 895420 & 397251 & 144718 & 245672 & 27913 & 4621645 \\
\hline
\end{tabular}

Energy balance, Sudan 2014

Unit: ktoe

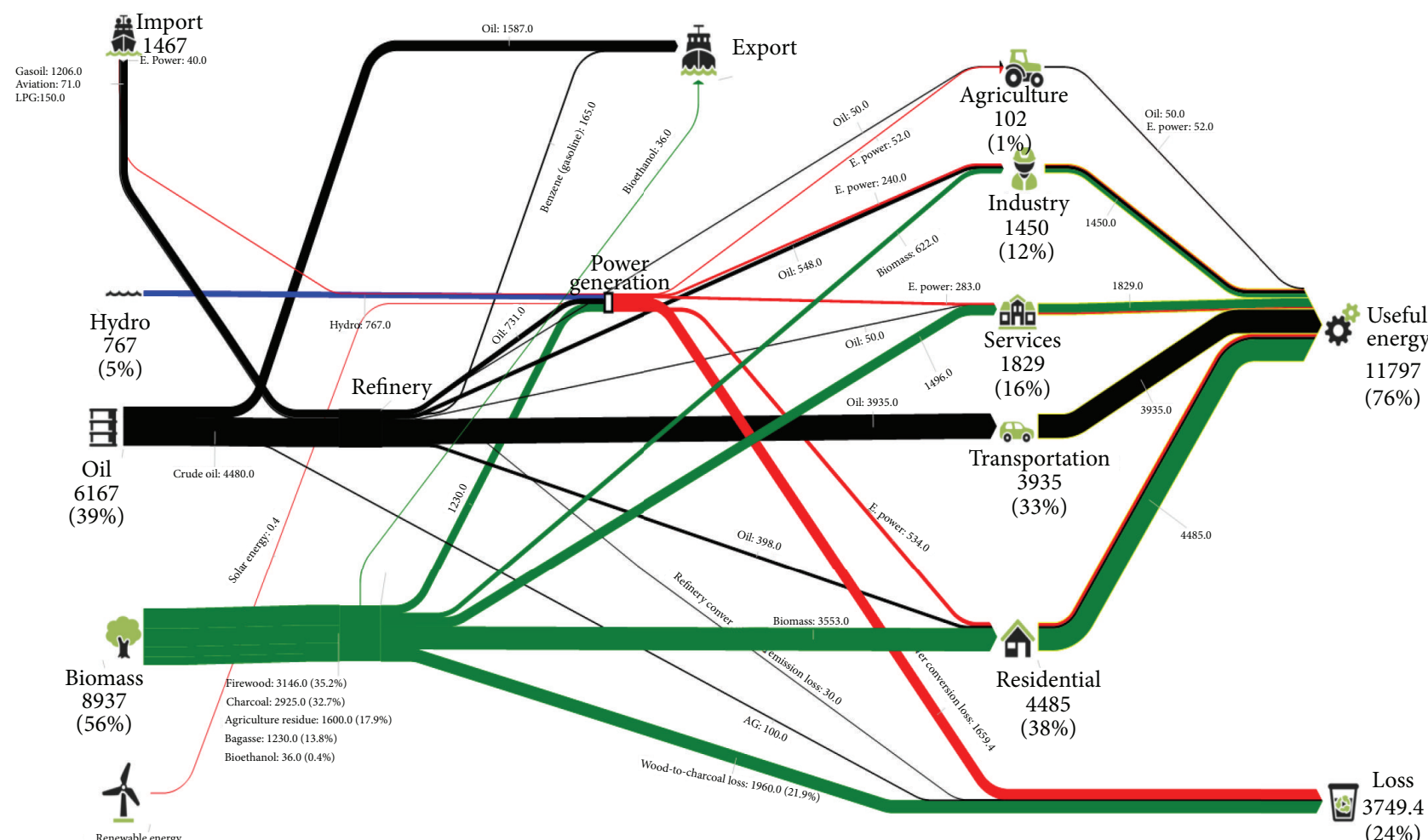

- Oil

E. power

- Hydro

- Biomass

- Solar energy

- Firewood

- Agriculture residue

- Charcoal

- Bagasse

- Aviation

- Bioethanol

- Gasoil

- Wood-to-charcoal loss

- Refinery conversion and emission loss

- LPG

- Benzene (gasoline)

- Power conversion loss

- Crude oil

- AG

FIGURE 4: Sankey diagram for Sudan. The data used is energy data for the year 2014. The data does not include private power generation. The renewable energy includes only solar photo voltaic power; the other types of energy, such as wind and geothermal, are not included. The hydro power and biomass energy are made as main categories in energy balance. The power generation efficiency and fuel conversion loss and emissions in the refinery are considered. All units are in ktoe (ton of oil equivalent).

loss. It is worth highlighting two examples of energy management loss:

(a) Lack of cogeneration in sugar industry: the potential electric power generation in sugar industry is double the present level if cogeneration in the sugar industry is introduced [12]. Cogeneration is the standard practice in sugar industry worldwide. Lack of cogeneration made the sugar industry in Sudan burn bagasse 
TABLE 15: Supply and demand balance (000 tonnes) [6].

\begin{tabular}{ccccccccccc}
\hline Year & Fuel oil & Gasoil & Kerosene & Benzene & LPG & Naphtha & AV & H. coker GO & Pet coke & Diesel \\
\hline 2010 & -295 & -79 & 22 & 418 & -33 & 20 & 35 & 380 & -19 & -26 \\
2011 & -257 & 47 & 20 & 311 & 173 & 20 & -5 & 321 & 74 & -22 \\
2012 & -248 & -227 & 5 & 231 & 59 & 8 & 3 & 277 & -20 \\
2013 & -124 & 15 & 15 & 91 & 127 & 18 & -28 & 254 & 66 & -31 \\
2014 & -75 & 64 & 13 & 154 & 50 & 17 & 24 & 292 & 15 \\
\hline
\end{tabular}

TABLE 16: Fuel demand for thermal electric power base year 2014 [9].

\begin{tabular}{lccccc}
\hline Fuel & Fuel oil & Benzene & H. coker GO & Pet coke & Diesel \\
\hline tonne & 222844 & 240981 & 162581 & 14899 & 33916 \\
ktoe & 214 & 258 & 156 & 11 & 325 \\
\hline
\end{tabular}

TABLE 17: Oil supply and demand in 2014.

\begin{tabular}{|c|c|c|c|c|}
\hline Item & & ktoe & $\%$ & Share $\%$ \\
\hline Crude oil production & & 6067 & 79.89 & \\
\hline Associated gas & & 100 & 1.32 & \\
\hline Gasoil & & 1206 & 15.88 & \\
\hline Aviation & & 71 & 0.93 & \\
\hline LPG & & 150 & 1.98 & \\
\hline Subtotal A & & 7594 & 100.00 & \\
\hline Flared AG & & 100 & 5.93 & 1.32 \\
\hline Crude export & & 1587 & 94.07 & 20.90 \\
\hline Subtotal B: export + loss & 1687 & & & \\
\hline Subtotal $\mathrm{C}=\mathrm{A}-\mathrm{B}$ & 5907 & & & \\
\hline Refinery conversion + distribution + emission & & 30 & 3.19 & \\
\hline Benzene export & & 165 & 17.82 & \\
\hline Power production & & 677 & 73.13 & \\
\hline KRC + ORC (internal consumption for power generation) & & 54 & 5.85 & \\
\hline Subtotal $\mathrm{D}=\mathrm{C}-$ oil used in power generation & 926 & & 100.00 & 12.19 \\
\hline Residential & & 398 & 8.00 & \\
\hline Transportation & & 3935 & 79.00 & \\
\hline${ }^{1}$ Service & & 50 & 1.00 & \\
\hline Industry & & 548 & 11.00 & \\
\hline Agric. & & 50 & 1.00 & \\
\hline Fuel for consumption by sectors & 4981 & & & 65.59 \\
\hline Total by sectors & 5907 & & 100.00 & 100.00 \\
\hline
\end{tabular}

${ }^{1}$ Service includes public buildings, school, universities, hospitals, municipals, and so forth.

inefficiently; otherwise bagasse poses serious hazard to factory safety.

(b) Flaring of AG: about 15 MMSCFD or 100 ktoe (1.7\% of the oil supply) is attributed to flaring of AG. In the oil fields, a significant amount of AG is produced. AG produced is, however, not utilized; it is rather flared. The study conducted by [14] indicated that AG is useful primary energy and if utilized in power generation it can drive steam turbine power plant of $80 \mathrm{MW}$ or can be utilized to produce LPG of annual value of $\$ 40 \mathrm{M} /$ year.

(3) Demand: $74 \%$ of the total energy demand is useful energy and $26 \%$ is loss. $49 \%$ of the total loss is due to low efficiency of conversion from wood to charcoal (charcoal conversion efficiency is $33 \%$ ). The useful energy is distributed among the various demand sectors: agriculture $(1 \%)$, service $(16 \%)$, industry (12\%), residential (39\%), and transportation (32\%) sectors.

The developed Sankey diagram is the first of its type in Sudan. The main differences between the present and previous energy balance are the following:

(1) The previous energy balance is presented in simple line draw diagram rather than a professional Sankey diagram as all lines representing different flows are of the same size. 
TABLE 18: Bagasse and bioethanol production [15].

\begin{tabular}{|c|c|c|c|c|c|c|c|c|c|c|}
\hline \multirow{2}{*}{ Year } & \multicolumn{7}{|c|}{ Capacity (000 tonnes/year) } & \multicolumn{2}{|c|}{ Bagasse } & \multirow{2}{*}{$\begin{array}{c}\text { Bioethanol }^{14} \\
\left(000 \mathrm{~m}^{3}\right)\end{array}$} \\
\hline & Kenana & New Halfa & Gunied & Sennar & Assalya & W Nile & Total & Mton & ktoe & \\
\hline 2002 & 376 & 85 & 94 & 78 & 64 & & 697 & 3059 & 1315 & \\
\hline 2003 & 398 & 83 & 87 & 85 & 76 & & 729 & 3200 & 1376 & \\
\hline 2004 & 428 & 88 & 87 & 79 & 74 & & 755 & 3314 & 1425 & \\
\hline 2005 & 393 & 73 & 87 & 72 & 88 & & 713 & 3127 & 1344 & \\
\hline 2006 & 400 & 85 & 81 & 81 & 81 & & 728 & 3195 & 1373 & \\
\hline 2007 & 405 & 83 & 87 & 93 & 90 & & 758 & 3326 & 1430 & \\
\hline 2008 & 402 & 81 & 85 & 86 & 91 & & 745 & 3268 & 1405 & \\
\hline 2009 & 382 & 84 & 88 & 87 & 98 & & 739 & 3241 & 1393 & \\
\hline 2010 & 276 & 57 & 88 & 77 & 75 & & 574 & 2518 & 1082 & \\
\hline 2011 & 356 & 75 & 98 & 71 & 94 & & 693 & 3040 & 1307 & 40 \\
\hline 2012 & 350 & 66 & 92 & 77 & 90 & 6 & 680 & 2985 & 1283 & 55 \\
\hline 2013 & 471 & 56 & 77 & 76 & 90 & 73 & 843 & 3698 & 1590 & 67 \\
\hline 2014 & 308 & 60 & 73 & 73 & 65 & 73 & 652 & 2862 & 1230 & 70 \\
\hline
\end{tabular}

${ }^{14}$ All bioethanol is produced from Kenana sugar factory.

TABLE 19: Firewood by state in $\mathrm{m}^{3}[8]$.

\begin{tabular}{lccccccc}
\hline Year & North & Khartoum & Central & Eastern & Kordofan & Darfur & Total \\
\hline 2005 & 4267 & 0 & 52087 & 31228 & 129324 & 10311 & 227217 \\
2006 & 3547 & 0 & 37632 & 16038 & 577803 & 138903 \\
2007 & 5379 & 0 & 70113 & 71116 & 23792 & 29079 \\
2008 & 5153 & 770 & 83808 & 33734 & 278401 & 64868 \\
2009 & 3000 & 0 & 39828 & 15360 & 0 & 0 & 469479 \\
2010 & 11855 & 0 & 75621 & 29140 & 127089 & 33056 \\
2011 & 6538 & 340 & 72992 & 34307 & 99828 & 276761 \\
2012 & 3410 & 500 & 49490 & 9753 & 6511 & 2595 \\
2013 & 3150 & 0 & 52079 & 8400 & 13837 & 0 & 72464 \\
2014 & 200 & 0 & 23757 & 9627 & 50144 \\
\hline
\end{tabular}

TABLE 20: Charcoal by state (tons) [8].

\begin{tabular}{|c|c|c|c|c|c|c|c|}
\hline Year & North & Khartoum & Central & Eastern & Kordofan & Darfur & Total \\
\hline 2005 & 895 & 0 & 29788 & 15615 & 5254 & 720 & 52272 \\
\hline 2006 & 912 & 0 & 10479 & 855 & 13201 & 2219 & 27665 \\
\hline 2007 & 1568 & 0 & 17239 & 507 & 0 & 1676 & 20990 \\
\hline 2008 & 1012 & 158 & 16016 & 42479 & 11820 & 1015 & 72501 \\
\hline 2009 & 0 & 0 & 310 & 2995 & 0 & 0 & 3305 \\
\hline 2010 & 8556 & 0 & 10004 & 30545 & 557026 & 1512 & 607643 \\
\hline 2011 & 19276 & 0 & 192198 & 39941 & 24109 & 70082 & 345606 \\
\hline 2012 & 0 & 0 & 3200 & 9875 & 0 & 0 & 13075 \\
\hline 2013 & 0 & 0 & 3500 & 5930 & 0 & 0 & 9430 \\
\hline 2014 & 0 & 0 & 1302 & 155 & 0 & 0 & 1457 \\
\hline
\end{tabular}

TABLE 21: Estimate firewood and charcoal.

\begin{tabular}{lccc}
\hline Source & $\begin{array}{c}\text { Firewood } \\
\text { ktoe }\end{array}$ & $\begin{array}{c}\text { Charcoal } \\
\text { ktoe }\end{array}$ & $\begin{array}{c}\text { Total as firewood } \\
\text { ktoe }\end{array}$ \\
\hline$[7]$ & 3146 & $878(2926)^{15}$ & 6072 \\
{$[16]$} & 2410 & $795(2650)$ & 5060 \\
{$[17]^{16}$} & 3944 & $1328(4427)$ & 8371 \\
\hline
\end{tabular}

${ }^{15}$ Data in brackets is firewood converted into charcoal with conversion efficiency of $33 \%$.

${ }^{16}$ The original data is given as consumption per capita. 
TABLE 22: Agriculture waste.

\begin{tabular}{|c|c|c|c|c|c|c|c|c|c|}
\hline \multirow{3}{*}{ Year } & Sorghum & \multirow{3}{*}{0.4} & \multirow{3}{*}{0.4} & $\begin{array}{l}\text { Groundnut } \\
\text { HI [11] }\end{array}$ & \multirow{3}{*}{0.52} & \multirow{3}{*}{0.52} & Cotton & \multicolumn{2}{|c|}{ Total residue } \\
\hline & \multirow[t]{2}{*}{0.4} & & & 0.52 & & & 0.16 & & \\
\hline & & & & kton/year & & & & Mton & ktoe \\
\hline 2002 & 4.394 & 578 & 247 & 990 & 274 & 4 & 72 & 2.79 & 2105 \\
\hline 2003 & 2.825 & 581 & 330 & 550 & 122 & 18 & 86 & 2.46 & 1852 \\
\hline 2004 & 4.69 & 769 & 398 & 790 & 399 & 7 & 66 & 3.21 & 2418 \\
\hline 2005 & 266 & 280 & 364 & 520 & 277 & 12 & 86 & 2.56 & 1932 \\
\hline 2006 & 4327 & 675 & 416 & 555 & 400 & 44 & 75 & 9.44 & 7117 \\
\hline 2007 & 4.999 & 796 & 669 & 564 & 242 & 73 & 61 & 3.34 & 2516 \\
\hline 2008 & 3.869 & 721 & 587 & 716 & 350 & 100 & 24 & 3.17 & 2389 \\
\hline 2009 & 4.197 & 637 & 641 & 942 & 318 & 247 & 31 & 3.48 & 2620 \\
\hline 2010 & 2.63 & 471 & 403 & 549 & 248 & 46 & 12 & 2.16 & 1624 \\
\hline 2011 & 4.605 & 634 & 292 & 1.185 & 363 & 124 & 14 & 1.92 & 1445 \\
\hline 2012 & 1.883 & 378 & 324 & 1.032 & 187 & 92 & 55 & 1.60 & 1208 \\
\hline 2013 & 4.524 & 1.09 & 265 & 1.767 & 562 & 86 & 25 & 1.14 & 857 \\
\hline 2014 & 2.249 & 359 & 193 & 963 & 205 & 56 & 31 & 2.12 & 1600 \\
\hline
\end{tabular}

TABLE 23: Animal waste.

\begin{tabular}{|c|c|c|c|c|c|c|}
\hline \multirow{3}{*}{ Year } & \multirow{3}{*}{$\begin{array}{l}\text { Cows } \\
10.95\end{array}$} & \multirow{2}{*}{\multicolumn{3}{|c|}{$\begin{array}{l}\text { Sheep } \quad \text { Goats } \\
\text { Dung production (tons/year/head) [10] }\end{array}$}} & \multirow{2}{*}{\multicolumn{2}{|c|}{ Dung }} \\
\hline & & & & & & \\
\hline & & 1.83 & 1.83 & 5.48 & Mton & ktoe \\
\hline \multicolumn{7}{|c|}{ Million head } \\
\hline 2002 & 39.479 & 48.136 & 41.485 & 3.343 & 61 & 25690 \\
\hline 2003 & 39.667 & 48.44 & 42.03 & 3.503 & 62 & 25878 \\
\hline 2004 & 39.76 & 48.91 & 42.179 & 3.519 & 62 & 25971 \\
\hline 2005 & 40.468 & 49.797 & 42.526 & 3.908 & 63 & 26479 \\
\hline 2006 & 40.994 & 50.39 & 42.756 & 4.078 & 64 & 26821 \\
\hline 2007 & 41.138 & 50.651 & 42.938 & 4.238 & 64 & 26958 \\
\hline 2008 & 41.426 & 51.067 & 43.104 & 4.46 & 65 & 27185 \\
\hline 2009 & 41.563 & 51.555 & 43.27 & 4.56 & 65 & 27321 \\
\hline 2010 & 41.761 & 52.079 & 43.441 & 4.623 & 66 & 27479 \\
\hline 2011 & 29.618 & 39.296 & 30.649 & 4.715 & 48 & 19986 \\
\hline 2012 & 29.84 & 39.483 & 30.837 & 4.751 & 48 & 20124 \\
\hline 2013 & 30.01 & 39.568 & 30.984 & 4.773 & 48 & 20225 \\
\hline 2014 & 30.191 & 39.846 & 31.029 & 4.792 & 49 & 20337 \\
\hline
\end{tabular}

(2) The energy balance accounts only for power produced by public sectors. For example, the electric power produced by the refinery and sugar factory is not accounted for in the overall balance. Likewise, renewable energy though small is not accounted for as well.

\section{Conclusion}

The study provides important information on Sudan's energy sector covering supply and demand sides as well as conversion, distribution, and transmission. For the supply detailed data on electric power generation, oil production and conversion, biomass sources and conversion, and renewable energy was given. Energy import and export were also reported. On the demand side, detailed data of different sectors is reported. The work provided energy flow diagram (Sankey diagram) for the first time. Sankey diagram is an important piece of information for decision-makers. It can be used to develop strategies and identify potential saving, opportunities, and mitigation measures. The weak point of Sudan's energy status is solar energy despite the high intensity of solar radiation and long sunshine hours across the country.

\section{Competing Interests}

The authors declare that there are no competing interests regarding the publication of this paper. 
TABLE 24: Biomass supply and demand.

\begin{tabular}{|c|c|c|c|c|c|}
\hline Supply & ktoe & $\%$ & Demand & ktoe & $\%$ \\
\hline Firewood & 3146 & 28.68 & Residential & 3553 & 32.39 \\
\hline Charcoal & $2925(965)^{17}$ & 26.66 & Services & 1496 & 13.64 \\
\hline Agricultural residue & 1600 & 14.58 & Industry & 662 & 6.03 \\
\hline Bagasse & 1230 & 11.21 & Transport & 0 & 0.00 \\
\hline Bioethanol & 36 & 0.33 & Agriculture & 0 & 0.00 \\
\hline \multirow[t]{4}{*}{ Animal waste } & $2034^{18}$ & 18.54 & Electric power & 1230 & 11.21 \\
\hline & & & Charcoal conversion loss & 1960 & 17.87 \\
\hline & & & Export $^{19}$ & 36 & 0.33 \\
\hline & & & Not utilized $^{20}$ & 2034 & 18.54 \\
\hline Total & 10971 & 100 & & 10971 & 100.00 \\
\hline
\end{tabular}

${ }^{17}$ Data in brackets is firewood converted into charcoal with conversion efficiency of $33 \%$.

${ }^{18}$ Animal waste is not considered as there is no record for animal waste utilization in the base year 2014 .

${ }^{19}$ All bioethanol is exported.

${ }^{20}$ Animal waste is not utilized.

\section{Acknowledgments}

The authors acknowledge the research grant by the Ministry of Higher Education and Scientific Research of Sudan.

\section{References}

[1] A. Kumar, Subramanyam, and V. R. Kabir, Development of Energy, Emission and Water Flow Sankey Diagrams for the Province of Alberta Through Modeling. University of Alberta, Department of Mechanical Engineering, Department of Energy, Government of Alberta, Alberta, Canada, 2011.

[2] IRG, "Energy Planning and Development of Carbon Mitigation Strategies-Using the MARKAL Family of Models," International Resource Group, Washington, DC, USA, 2010.

[3] M. A. Jaccard, Estimating the Effect of the Canadian Government's 2006-2007 Greenhouse Gas Policies, C. D. Howe Institute, Toronto, Canada, 2007.

[4] O. Bahn, L. Barreto, B. Büeler, and S. Kypreos, "A multi-regional MARKAL-MACRO model to study an international market of $\mathrm{CO}_{2}$ emission permits: a detailed analysis of a burden sharing strategy among the Netherlands, Sweden and Switzerland," PSI Technical Paper, Paul Scherrer Institut (PSI), Villigen, Switzerland, 1998.

[5] Quadrennial Technology Review, An Assessment of Energy Technologies and Research Opportunity, Department of Energy, Washington, DC, USA, 2015, http://energy.gov/sites/prod/ files/2015/09/f26/Quadrennial-Technology-Review-2015_0.pdf.

[6] MOF, Study of Causes of Demand Increase on Oil Product and Options and Strategy of Subsidy Removal, Ministry of Finance, Khartoum, Sudan, 2014.

[7] AEC, "Sudan energy status," in Proceedings of the 10th Arab Energy Conference, Energy and Arab Corporation, Abudabi, UAE, 2014.

[8] Directorate of Agriculture and Forestry (DAF), Annual Report, Directorate of Agriculture and Forestry (DAF), Khartoum, Sudan, 2014.

[9] NEC, Executive Summary for Year 2014, National Thermal Electricity Corporation, Khartoum, Sudan, 2014.

[10] M. Niamir, Report on Animal Husbandry among the Ngok Dinka of the Sudan-Integrated Rural, Sudan and Harvard Institute for International Elation, Khartoum, Sudan, 1982.
[11] V. Smil, "Crop residues: agriculture's largest harvest," BioScience, vol. 49, no. 4, pp. 299-308, 1999.

[12] A. A. Rabah, "Future of sugar industry in Sudan," Sudanese Engineering Journal, vol. 5, no. 3, pp. 60-64, 2013.

[13] A. M. Omer, "Energy, environment, and sustainable development in Sudan," IIOAB Journal, vol. 2, no. 1, pp. 31-44, 2011.

[14] W. Abdelhamid, Flared gas uilization [M.S. thesis], Chemical Engineering, University of Khartoum, Khartoum, Sudan, 2013.

[15] M. Bashir, B. M. Elhassan, and A. A. Rabah, "Assessment of standby evaporator as an energy conservation measure: case of sudanese sugar industry," Sugar Tech, vol. 13, no. 3, pp. 179-184, 2011.

[16] A. M. Omer, "The environmental and economical advantages of agricultural wastes for sustainability development in Sudan," Journal of Brewing and Distilling, vol. 1, no. 1, pp. 1-10, 2010.

[17] G. E. Ali, Studies on Consumption of Forest Products in the Sudan-Woodfuel Consumption in the Household Sector, Energy Research Institute, Khartoum, Sudan, 1994. 

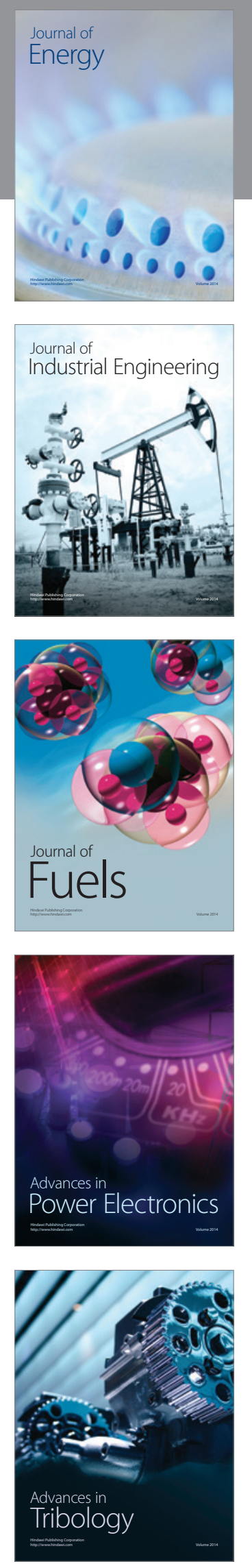
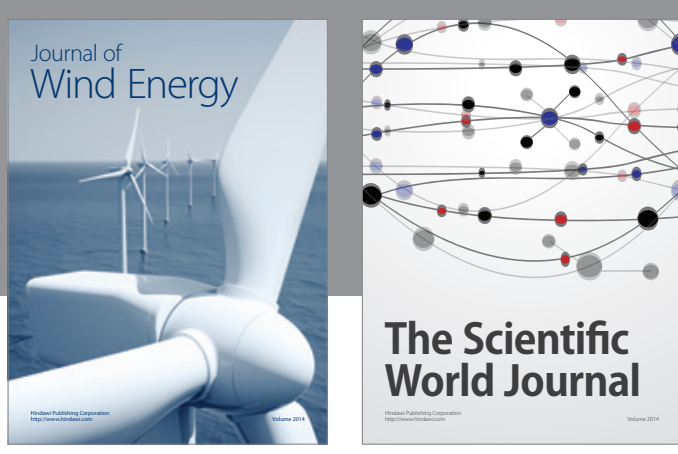

The Scientific World Journal
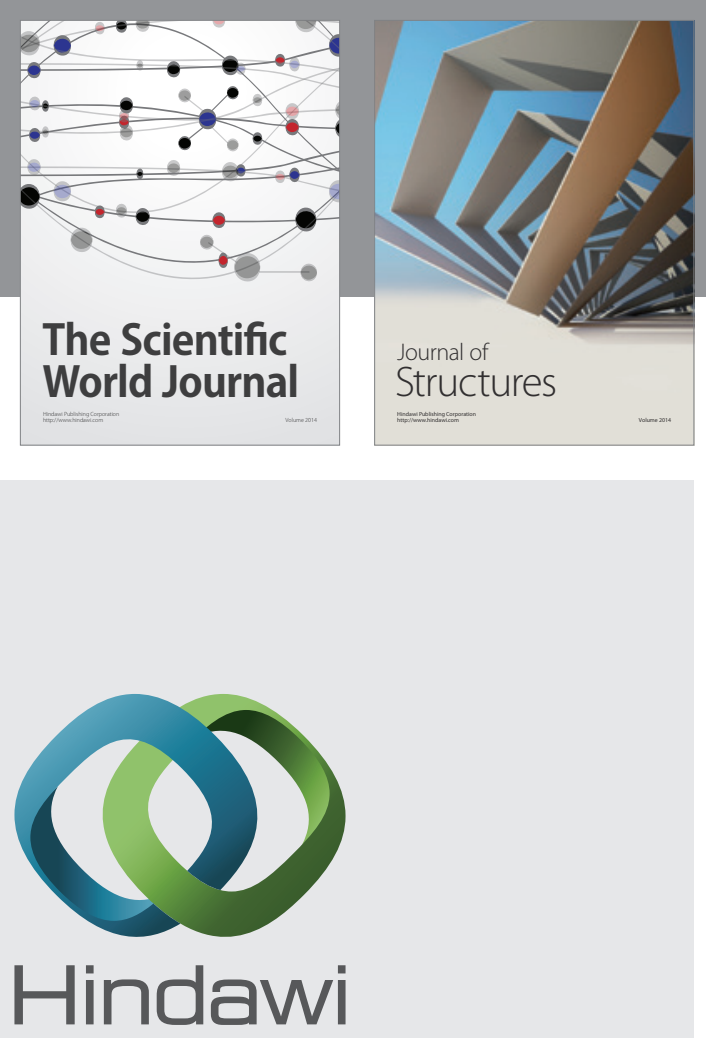

Submit your manuscripts at

http://www.hindawi.com
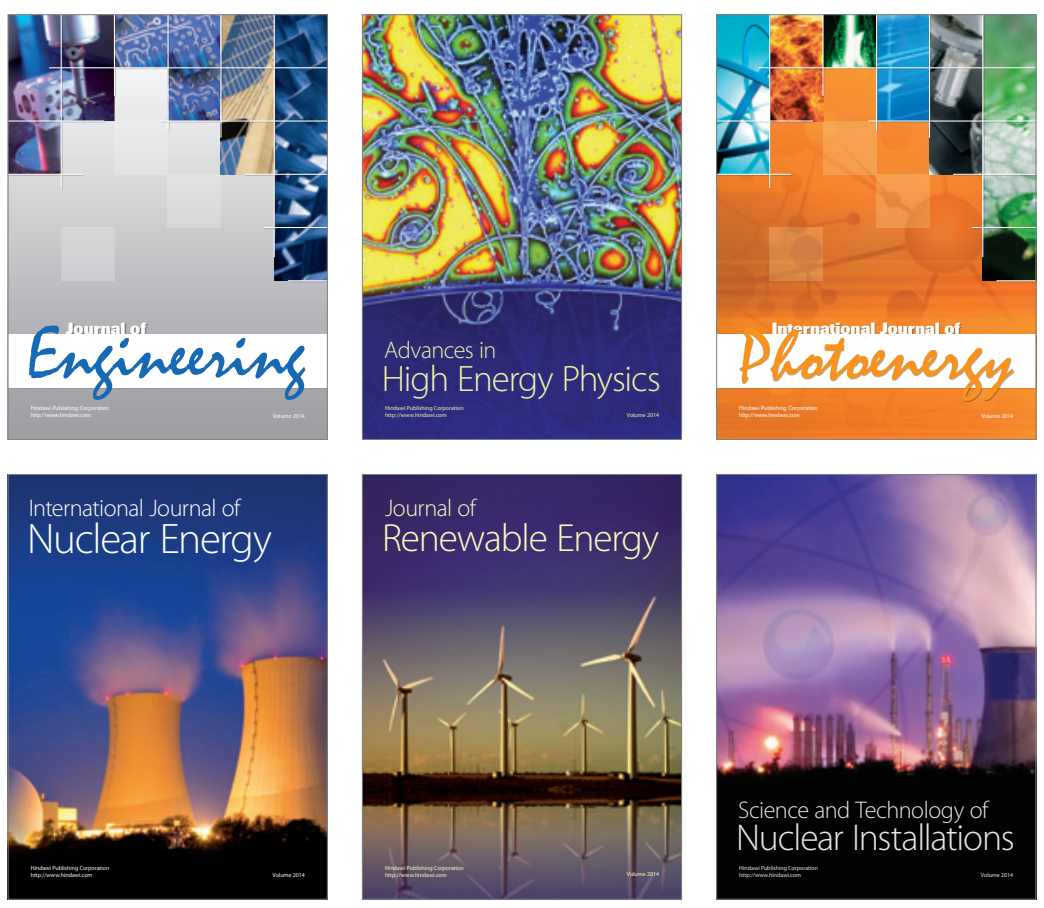
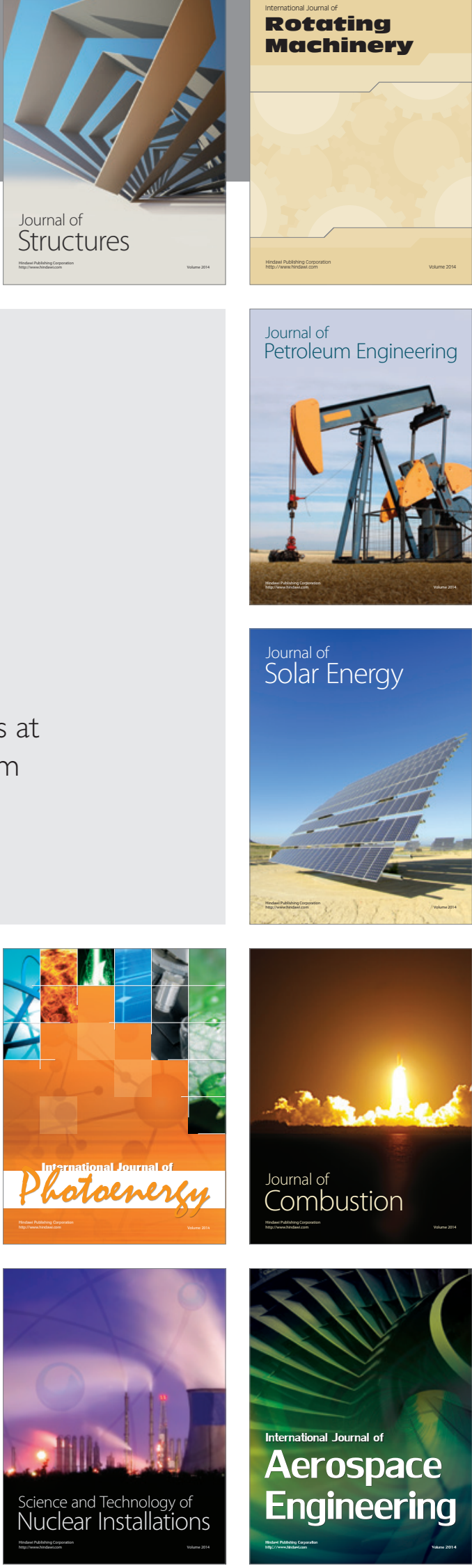